Available online on 15.12.2019 at http://ajprd.com
(c) 2013-19, publisher and licensee AJPRD, This is an Open Access article which permits unrestricted non-
commercial use, provided the original work is properly cited

Open $\overbrace{\text { Access }}$

Research Article

\title{
Assessment of In-Vivo Antioxidant Potential of Hydro-Alcoholic Extract and Ethyl Acetate Fraction of Aerva Javanica Linn. Flowering Tops
}

\section{Khunteta Alok ${ }^{1}$, Swarnkar Surendra K.1*, Gupta Manish Kumar ${ }^{1 *}$ Swarnkar Aruna ${ }^{3}$, Sharma Swapnil ${ }^{4}$, Paliwal Sarvesh4}

1. LBS College of Pharmacy, Jaipur-302004, Rajasthan, India

2. School of Pharmaceutical Sciences, Jaipur National University, Jaipur-302017, Rajasthan, India

3. SMS Medical College, Jaipur-302004, Rajasthan, India

4. Department of Pharmacy, Banasthali Vidyapith, Banasthali, Newai, Rajasthan, India

\begin{abstract}
A B S T R A C T
Aerva javanica (Amaranthaceae) is a grey coloured woolly perennial tomentose shrub. Its traditional and folklore usage motivates further investigation on its pharmacognostic parameters and pharmacological potential. Hydro-alcoholic extract (AJCE) was prepared from flowering tops of A. javanica. In order to work further on activity guided fractions, ethyl acetate (AJEAF) fraction was prepared. Therefore, in order to establish its antioxidant potential, in-vivo effect on LPO, GSH, SOD and catalase activity was determined. For comparison, silymarin and Centella asiatica extract (CAE) were used as standard antioxidant compound/extract. Lipid peroxidation in term of MDA content expressed as $\mathrm{nM} / \mathrm{mg}$, which was 82.18 and 67.39 for AJCE with increasing doses of complete hydro-alcoholic extract (AJCE represented as AJCE-1 and AJCE-2) and 51.65 for AJEAF in contrast to $40.64 \mathrm{nM} / \mathrm{mg}$ for standard silymarin and $46.81 \mathrm{nM} / \mathrm{mg}$ for standard CAE. GSH content was determined as $3.12,3.82$ and $4.56 \mu \mathrm{g} / \mathrm{mg}$ wet tissue in contrast to 5.59 for standard silymarin and 4.42 for standard CAE. Superoxide scavenging was expressed as SOD U/mg wet tissue, determined as 7.26, 9.16 and $9.91 \mathrm{U} / \mathrm{mg}$ wet tissue for AJCE-1 (250 mg/kg i.p. b.w), AJCE-2 (500 mg/kg i.p. b.w), and AJEAF respectively in comparison to silymarin (10.11) and CAE (46.81 U/mg wet tissue). Catalase activity expressed as $\mu \mathrm{M}$ of $\mathrm{H}_{2} \mathrm{O}_{2}$ decomposed / min / $\mathrm{mg}$ wet tissue was determined as $0.61,0.72$ and 0.78 repectively for AJCE-1 (250 mg/kg i.p. b.w), AJCE-2 $(500 \mathrm{mg} / \mathrm{kg}$ i.p. b.w), and AJEAF. Results indicated the SOD values and total antioxidant power of DEE and EAF fractions even better than standard ascorbic acid which expressed the prospective potential of fractions (DEE and EAF) against metabolic disorders.
\end{abstract}

Keywords:_ Patharphori, Tris, OECD, TBARS, Malondialdehyde, Silymarin

A R T I C L E I N F 0: Received 17 Sept. 2019; $\quad$ Review Completed 25 Nov. 2019; $\quad$ Accepted 06 Dec. 2019; $\quad$ Available online 15 Dec. 2019

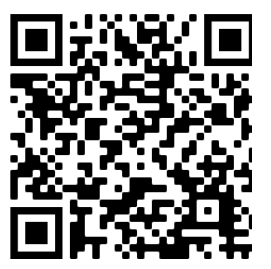

Cite this article as:

Khunteta A, Swarnkar SK., Gupta MK, Swarnkar A, Sharma S, Paliwal S, Assessment of In-Vivo Antioxidant Potential of Hydro-Alcoholic Extract and Ethyl Acetate Fraction of Aerva Javanica Linn. Flowering Tops, Asian Journal of Pharmaceutical Research and Development. 2019; 7(6):72-78, DOI: http://dx.doi.org/10.22270/ajprd.v7i6.614

*Address for Correspondence:

Surendra Kumar Swarnkar, LBS College of Pharmacy, Udai Marg, Tilak Nagar, Jaipur- Rajasthan, India

\section{INTRODUCTION}

$\mathrm{F}$ olklore usage of herbs in various ailments motivates research of traditional drugs in modern system. Indigenous medical system is much more explored to develop drugs from plants. ${ }^{1}$ Traditional use of Aerva javanica flower tops in is the basis of present study. Chopra (1956) reported its traditional use as demulcent, diuretic, anthelmintic and also in headache. Swellings were reported to be removed by administration of plant decoction..$^{2-3}$ Aerva javanica Linn. (Amaranthaceae) also known as 'Patharphori', is a grey colored woolly, perennial, suffruticose, hoary-tomentose, erect to scandent dioecious conspicuous under shrub, 0.6- $1 \mathrm{~m}$ tall. ${ }^{4-5}$ Phyto-chemical standardization and in-vitro antioxidant potential of aerva extracts were determined by Swarnkar et al. ${ }^{6-8}$ The present study was undertaken to evaluate the extract and its fractions 
for their involvement in scavenging of oxidative radicals invivo. In this order, their in-vivo effect on LPO, GSH, SOD and catalase activity was evaluated.

\section{MATERIALS AND METHODS}

Materials: Absolute ethanol, acetate buffer ( $\mathrm{pH}$ 3.6) (SD finechem), silymarin (Himedia), Centella asiatica extract (Indian herbs), DMSO (Rankem), Malondialdehyde (MDA) (Himedia), methanol, sodium dodecyl sulfate (SDS) (Rankem), sulphuric acid (Rankem), Thio barbituric Acid (TBA), tricholoro acetic acid (TCA) (Rankem), Tris- $\mathrm{HCl}$ buffer (16 mM, pH 8.0), Ellman's reagent (Himedia).

Collection and extraction: Aerva javanica flowering tops were collected from forests of Jhalana in periphery of Jaipur, Rajasthan and authentication was done at "Department of Botany, University of Rajasthan, Jaipur" (Voucher specimen no. RUBL211644) (Authentication certificate Ref. no.: Bot/2017/5424 dated 13/02/2017).

Hydro-alcoholic (50\%) extract was prepared from air dried plant materials using maceration method. Fractionation was carried out by first defatting and then with solvents of increasing polarity (dielectric constant). Solvents used for this purpose were petroleum ether, diethyl ether, ethyl acetate, benzene, acetone, and ethanol. Whole hydroalcoholic extract (AJCE) and ethyl acetate fraction (AJEAF) were further used to assess antioxidant potential. ${ }^{9}$

Selection and preparation of animals and doses: Male wistar rats $(180-220 \mathrm{~g})$ were used for the present study. Animals were kept in well ventilated animal house maintained at standard environmental conditions (temperature $25 \pm 2^{\circ} \mathrm{C}$ relative humidity: $55-65 \%$ and $12 \mathrm{~h}$ light/dark cycle) at Department of Pharmacy, Banasthali Vidyapith, Rajasthan. Animals were provided with standard diet with complete access to water during entire experiment. The present protocol was approved by Institutional animal ethical committee (IAEC) of Banasthali Vidyapith, Rajasthan (Approval no. BV/3632/2017-2018). All the animal handling, maintainence and procedures were carried out in accordance to CPCSEA guideline. ${ }^{9-10}$

Toxicity studies: Acute toxicity of AJCE and AJEAF was determined in wistar rats, in accordance to OECD-423 guidelines. Overnight fasted group of rats $(n=3)$ were administered with graded doses $(50-2000 \mathrm{mg} / \mathrm{kg}$, p.o.) of extracts respectively. After administration, rats were observed for alteration in behavior of animals, gait abnormality, signs of nervous manifestations, discomfort if any, up to 14 days with special attention during first 4 hours.

\section{In-vivo antioxidant evaluation}

After one week of acclimatization rats were divided into various groups of control $(0.5 \% \mathrm{w} / \mathrm{v}$ sodium $\mathrm{CMC})$, treatment and standard and received treatment for 8 days ${ }^{13}$. Silymarin $(25 \mathrm{mg} / \mathrm{Kg}$ body weight p.o.) and Centella asiatica extract (CAE) $(500 \mathrm{mg} / \mathrm{Kg}$ body weight p.o.) were used as standard. Centella asiatica being an established herb having antioxidant potential, was selected as herbal standard extract, to compare activity of extracts in study. Extract treatment groups were divided as AJCE-1 (low dose $250 \mathrm{mg} / \mathrm{Kg}$ body weight p.o.) AJCE-2 (500mg/Kg body weight p.o.) and AJEAF (250mg/Kg body weight p.o.). All treatment groups received $\mathrm{CCl}_{4}$ in liquid paraffin (1:2) $(1.0 \mathrm{ml} / \mathrm{kg}$ i.p.) once in every $72 \mathrm{~h}$ along with treatment.

Tissue sample preparation: For lipid peroxidation (LPO), glutathione (GSH) and superoxide dismutase (SOD) assay, after $24 \mathrm{~h}$ of the last dose, animals were euthanized and livers were separated for further studies. $1 \mathrm{~g}$ of tissue was taken from each liver collected, washed out with normal saline and soaked in tissue papers. Collected liver tissues were then homogenized in $10 \mathrm{ml}$ of $0.15 \mathrm{M}$ tris buffer (pH-7.4) and supernatant was collected by centrifugation at $3000 \mathrm{~g}$ at $4{ }^{\circ} \mathrm{C}$ for $30 \mathrm{~min}$. Supernatants were then used for glutathione, lipid peroxidation and superoxide dismutase assays.

In order to prepare tissue sample for catalase assay, $900 \mathrm{mg}$ of tissue sample was taken from each liver collected from experimental rats, washed in normal saline soaked in tissue paper. The tissues were then homogenized in $3.0 \mathrm{ml} \mathrm{M} / 150$ phosphate buffer (pH-7.0) and supernatant was collected after centrifugation at $3000 \mathrm{~g}$ at $4^{\circ} \mathrm{C}$ for $1 \mathrm{hr}$. The supernatant was used for the assay.

\section{Determination of the Lipid Peroxidation (LPO)}

Lipid Peroxidation (LPO) being an autocatalytic process, is a common consequence of cell death. Inflammation, cancer and toxicity of xenobiotics and aging are being caused due to the peroxidative tissue damage resulted by LPO. One of the end product of this lipid peroxidation process is malondialdehyde (MDA), formed during oxidative degeneration. It is a product of free oxygen radicals, and used as a lipid peroxidation indicator. LPO was determined in homogenate by measuring the amounts of malondialdehyde (MDA). ${ }^{14}$

$1 \mathrm{ml}$ of tissue homogenate was mixed well with $1 \mathrm{ml}$ of normal saline $(0.9 \% \mathrm{w} / \mathrm{v})$ and $2.0 \mathrm{ml}$ of $(10 \% \mathrm{w} / \mathrm{v})$ TCA. It was then centrifuged for $10 \mathrm{~min}$ at room temperature at 3000 $\mathrm{g}$ to separate proteins. Supernatant was withdrawn and $2 \mathrm{ml}$ of it was added with $0.5 \mathrm{ml}(1.0 \% \mathrm{w} / \mathrm{v})$ thiobarbituric acid (TBA) and heated at $95^{\circ} \mathrm{C}$ for $60 \mathrm{~min}$. Pink colour of MDA was generated. Optical density (OD) of the pink coloured samples was measured at $532 \mathrm{~nm}$ using UV spectrophotometer.

LPO activity resulted in lipid peroxides and expressed in terms of $\mathrm{nM}$ of $\mathrm{MDA} / \mathrm{mg}$ wet tissue. The concentration of thiobarbituric acid reactive substances (TBARS) was calculated using the molar extinction coefficient of MDA $\left(1.56 \times 10^{5} \mathrm{~mol} / \mathrm{L} / \mathrm{cm}\right)$ using the formula, $\mathrm{A}=\Sigma \mathrm{CL}$, where A $=$ absorbance, $\Sigma=$ molar coefficient, $\mathrm{C}=$ concentration, and $\mathrm{L}=$ path length. The results were expressed in $\mathrm{nmol} / \mathrm{mg}$ of protein. ${ }^{15-16}$

\section{Determination of Superoxide Dismutase (SOD)}

Marklund and Marklund devised the assay method of superoxide dismutase (SOD) activity (17). Tris-EDTA: 49.78 $\mathrm{mM}$ Tris in distilled water, $0.0012 \mathrm{mM}$ EDTA in distilled water; $\mathrm{pH}$ 8.5; Pyrogallol- $2 \mathrm{mM}$ in distilled water. $2.8 \mathrm{ml}$ Tris-EDTA was mixed with of $100 \mu \mathrm{l}$ pyrogallol was taken as blank and taken in the cuvette scanned for 3 min at $420 \mathrm{~nm}$ wavelength. Then same process was followed with $2.8 \mathrm{ml}$ 
Tris-EDTA mixed with of $100 \mu 1$ pyrogallol and $50 \mu 1$ of liver homogenate. Enzyme activity was defined in terms of equivalents of SOD units. One SOD unit, as expressed by Units/mg protein/min, is the amount of SOD enzyme inhibiting the rate of pyrogallol auto oxidation by $50 \% .^{13}$ The enzyme unit can be calculated by using the following equations:

$$
\begin{gathered}
\text { Rate }(R)=\frac{\left(O D_{\text {final }}-O D_{\text {initial }}\right)}{3 \mathrm{~min}} \\
\% \text { of inhibition }=\frac{\left(O D_{\text {blank }}-\mathrm{R}\right)}{O D_{\text {blank }}} \mathrm{X} 100 \\
\text { Enzyme unit }(U)=\frac{\text { \%inhibition }}{50} \mathrm{X} \text { common dilution factor }
\end{gathered}
$$

where, $50 \%$ inhibition $\equiv 1 \mathrm{U}$ of enzyme activity

\section{Determination of Catalase activity}

Catalase enzyme breaks down the $\mathrm{H}_{2} \mathrm{O}_{2}$. Measurement of catalase activity is therefore based on this principal. $10 \mu \mathrm{l}$ of either sample was mixed with $3.0 \mathrm{ml}$ of $\mathrm{H}_{2} \mathrm{O}_{2}$ in phosphate buffer (M/15 phosphate buffer; pH- 7.0). Change in optical density was observed till it changes by 0.05 observed at 240 $\mathrm{nm}$ in UV spectrophotometer. Observations were made against blank. For blank an enzyme source was used in hydrogen peroxide $\left(\mathrm{H}_{2} \mathrm{O}_{2}\right)$ free phosphate buffer $(0.16 \mathrm{ml}$ of hydrogen peroxide is $30 \% \mathrm{w} / \mathrm{v}$ and was diluted by phosphate buffer to $100 \mathrm{ml}$ ). Enzyme was added and its absorbance was observed at $240 \mathrm{~nm} ; \Delta \mathrm{t}$ was observed till $0.45 \mathrm{OD}$. If $\Delta \mathrm{t}$ goes greater than 60 seconds, enzyme samples were used with concentration and the process was repeated. Observations were made at every 3 second interval. ${ }^{18}$ One unit enzyme activity is the amount of catalase enzyme that at $25^{\circ} \mathrm{C}$ liberates half the peroxide oxygen in 100 seconds from hydrogen peroxide $\left(\mathrm{H}_{2} \mathrm{O}_{2}\right)$ solution of any concentration. CAT activity is expressed in term of moles of hydrogen peroxide per minute as units per mg using following formula:

$$
\begin{aligned}
& \text { Moles of } \mathrm{H}_{2} \mathrm{O}_{2} \text { consumed } / \mathrm{min} \text { (units } / \mathrm{mg} \text { ) } \\
& \qquad=\frac{2.3}{\Delta t} * \ln \left(E_{\text {initia l l }} / E_{\text {final }}\right) * 1.63 * 10^{-3}
\end{aligned}
$$

Where, $\mathrm{E}=$ optical density of sample at $240 \mathrm{~nm}, \Delta \mathrm{t}=$ time required for a change in absorbance till 0.45

\section{Determination of reduced Glutathione (GSH)}

Activity of glutathione was assayed as reduced glutathione (GSH) as per the method of Ellman ${ }^{19}$. Reduction in glutathione was determined spectrophotometrically by estimation of Dithiobis-(2-nitrobenzoic acid) (DTNB) reduced by thiol (-SH) groups, expressed as microgram per milligram $(\mu \mathrm{g} / \mathrm{mg})$ wet tissue. $0.1 \mathrm{ml}$ of tissue sample was taken with $2.4 \mathrm{ml}$ of EDTA $(0.02 \mathrm{M})$ solution. Mixture was kept on ice bath for $10 \mathrm{~min}$. To the mixture, $2 \mathrm{ml}$ of distilled water and $0.5 \mathrm{ml}$ of tricholoro acetic acid (TCA) $(50 \% \mathrm{w} / \mathrm{v})$ were added. This mixture was ice chilled in ice bath for 10-
$15 \mathrm{~min}$, then centrifuged for $15 \mathrm{~min}$ at $3000 \mathrm{~g}$. To $1 \mathrm{ml}$ of supernatant was withdrawn and $2.0 \mathrm{ml}$ of $0.4 \mathrm{M}$ Tris buffer was added to it. Then $0.05 \mathrm{ml}$ of Ellman's reagent $(0.01 \mathrm{M}$ DTNB in methanol) was added to it and vortexed thoroughly. Mixture was scanned for OD (without much delay i.e. within 2-3 min after the addition of Ellman's reagent) at $412 \mathrm{~nm}$ in UV spectrophotometer against a reagent blank.

\section{RESULTS AND DISCUSSIONS}

Acute oral toxicity: Acute toxicities of extracts were determined on female wistar rats using OECD guidelines 423. ${ }^{11}$ Results of acute toxicity revealed that extracts were safe up to $2000 \mathrm{mg} / \mathrm{kg}$ and did not cause any signs of toxicity in rats. No mortality and neurological, behavioural and additional toxicity symptoms were observed with any of selected doses.

Based on observations, it was evident that there was no reduction in alertness, spontaneous motor activity, reactivity to sound and touch, body and limb tone. Respiration, urination, pupil size and pineal, corneal and righting reflexes were found normal for all 14 days of study. Abnormal signs pertaining to toxicity such as ataxia, body tremors, convulsions, lacrimation, salivation, diarrhoea, writhing, pilo-erection, sedation, coma, cyanosis etc. were not observed in all groups during experimental tenure of 14 days. Maximum tolerated dose (MTD) of extract was determined as $2000 \mathrm{mg} / \mathrm{kg}$ body weight.

Selection of dose: On the basis of results of acute toxicity studies, two doses i.e. $250 \mathrm{mg} / \mathrm{kg}$ body weight and 500 $\mathrm{mg} / \mathrm{kg}$ body weight (1/8 and 1/4 of MTD) for extract were selected for further pharmacological studies. For fractions only $1 / 8$ of MTD was selected as dose equivalent to 250 $\mathrm{mg} / \mathrm{kg}$ body weight.

Antioxidant potential of AJCE extract and its ethyl acetate fraction was shown in-vivo using male wistar rats. Endogenous enzymes that affect oxidation process in body are lipid peroxidase (LPO), superoxide dismutase (SOD) and catalase (CAT). Level of endogenous enzymes affecting oxidation process was estimated in tissues. Methods used include LPO, SOD and CAT assay. Level of glutathione (GSH) was also estimated. Silymarin $(25 \mathrm{mg} / \mathrm{kg})$ and Centella asiatica extract (CAE- $250 \mathrm{mg} / \mathrm{kg}$ ) were used as standard. After 8 days of treatment with extracts and standards, estimation of levels of LPO, SOD, CAT and GSH was carried out in homogenized liver tissues. LPO level was determined by estimating level of MDA (Okawa, 1979), SOD level by using method described by Marklund (1974), CAT level by method used by Sumner (1947) and GSH by Ellman's method (1959) using UV-Vis spectrophotometer. All results are expressed as mean \pm S.E.M. 
Table 1: In-vivo antioxidant assay- effect of extracts on various enzymes and non-enzymatic oxidative systems

\begin{tabular}{|l|l|l|l|l|}
\hline Treatment & $\begin{array}{c}\text { Lipid Peroxidation [MDA } \\
\text { content] (in nM/mg) }\end{array}$ & $\begin{array}{c}\text { SOD (U/mg } \\
\text { wet tissue) }\end{array}$ & $\begin{array}{c}\text { CAT ( } \boldsymbol{\mu M} \text { of } \mathbf{H}_{2} \mathbf{O}_{2} \\
\text { decomposed / min / mg wet } \\
\text { tissue) }\end{array}$ & $\begin{array}{c}\text { GSH content } \\
\text { ( } \boldsymbol{\mu g} / \mathbf{m g} \text { wet tissue) }\end{array}$ \\
\hline $\begin{array}{l}\text { Normal } \\
\text { control }\end{array}$ & $21.21 \pm 0.976$ & $10.29 \pm 0.135$ & $1.06 \pm 0.054$ & $5.68 \pm 0.096$ \\
\hline $\begin{array}{l}\text { CCl }_{4} \text { control } \\
\text { Silymarin }\end{array}$ & $40.64 \pm 1.242$ & $6.89 \pm 0.115$ & $0.51 \pm 0.045$ & $2.11 \pm 0.084$ \\
\hline AJCE-1 & $82.18 \pm 1.231$ & $10.11 \pm 0.138$ & $0.93 \pm 0.036$ & $5.59 \pm 0.097$ \\
\hline AJCE-2 & $67.39 \pm 1.786$ & $7.26 \pm 0.117$ & $0.61 \pm 0.048$ & $3.12 \pm 0.074$ \\
\hline AJEAF & $51.65 \pm 1.289$ & $9.16 \pm 0.154$ & $0.72 \pm 0.053$ & $3.83 \pm 0.059$ \\
\hline CAE* & $46.81 \pm 1.313$ & $9.91 \pm 0.143$ & $0.78 \pm 0.058$ & $4.56 \pm 0.031$ \\
\hline
\end{tabular}

Treatment groups received $\mathrm{CCl}_{4}$ in liquid paraffin $(1: 2)(1.0 \mathrm{ml} / \mathrm{kg}$ i.p. $)$ once in every $72 \mathrm{~h}$ along with treatment. Dosing was done daily for 8 days.

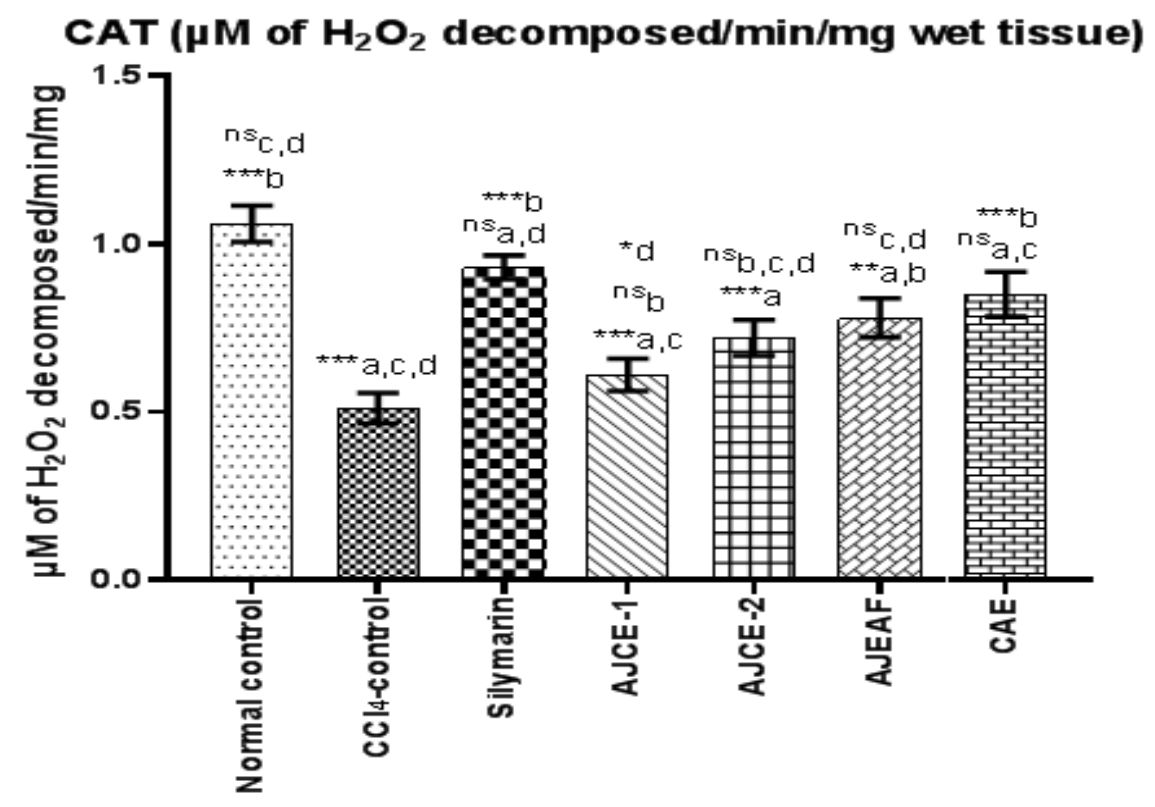

Results analyzed statistically using 1-way ANOVA followed by post hoc Tukey's multi-comparison test. Results compared with control (a), CCl4 control, standard silymarin (c) and CAE (d) herbal standard with all groups. Significance level represented as * $(\mathrm{p}<0.05)$, ** $(\mathrm{p}<0.01)$, *** (p,0.001), ns- no significant different.

Figure1: In-vivo antioxidant activity- effect on Catalase activity 


\section{GSH content ( $\mu \mathrm{g} / \mathrm{mg}$ wet tiss ue)}

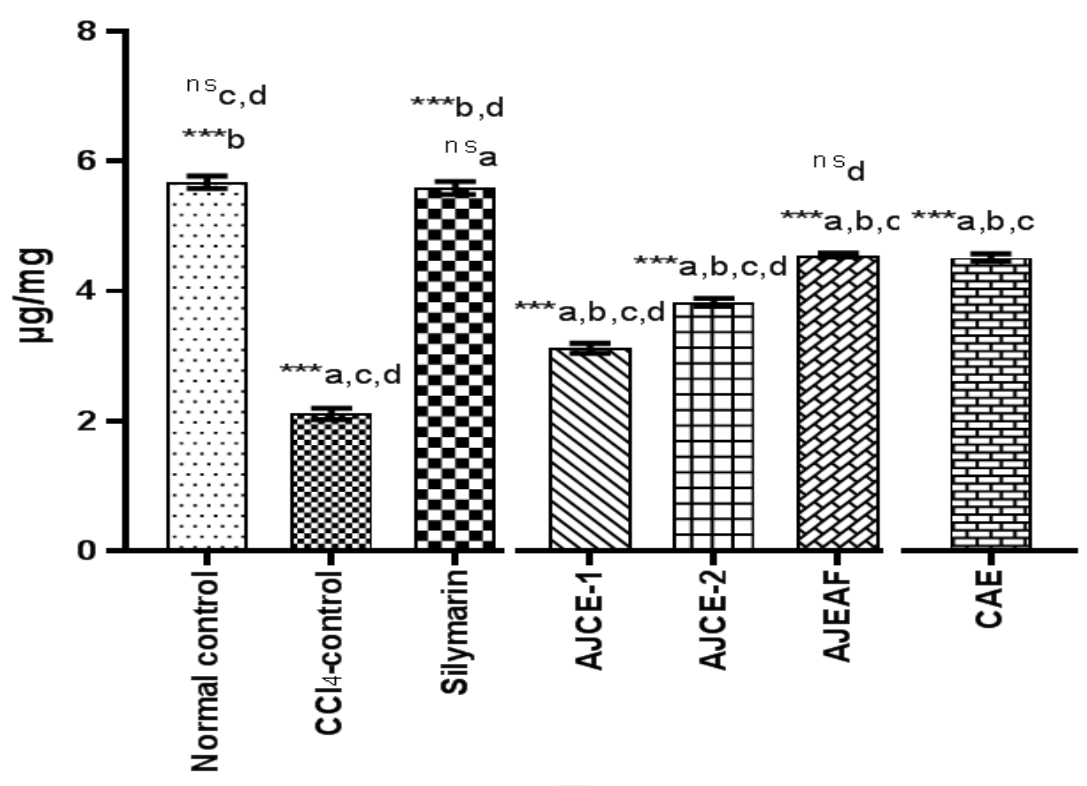

Results analyzed statistically using 1-way ANOVA followed by post hoc Tukey's multi-comparison test. Results compared with control (a), CCl4 control, standard silymarin (c) and CAE (d) herbal standard with all groups. Significance level represented as * $(\mathrm{p}<0.05), * *(\mathrm{p}<0.01), * * *(\mathrm{p}, 0.001)$, ns- no significant different.

Figure 2: In-vivo antioxidant activity- effect on GSH activity

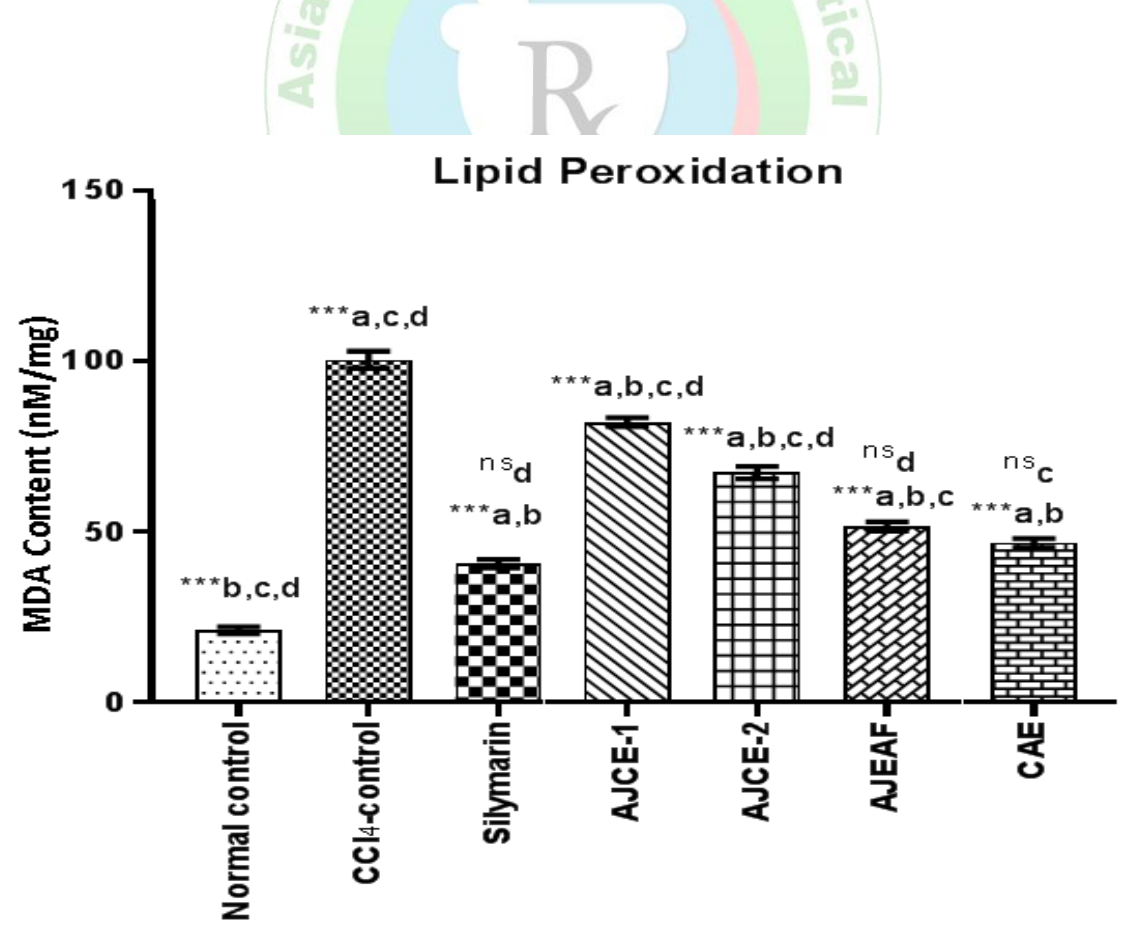

Results analyzed statistically using 1-way ANOVA followed by post hoc Tukey's multi-comparison test. Results compared with control (a), CCl4 control, standard silymarin (c) and CAE (d) herbal standard with all groups. Significance level represented as * $(\mathrm{p}<0.05),{ }^{* *}(\mathrm{p}<0.01),{ }^{* * *}(\mathrm{p}, 0.001)$, ns- no significant different.

Figure 3: In-vivo antioxidant activity- effect on lipid peroxidation activity 


\section{SOD (U/mg wet tissue )}

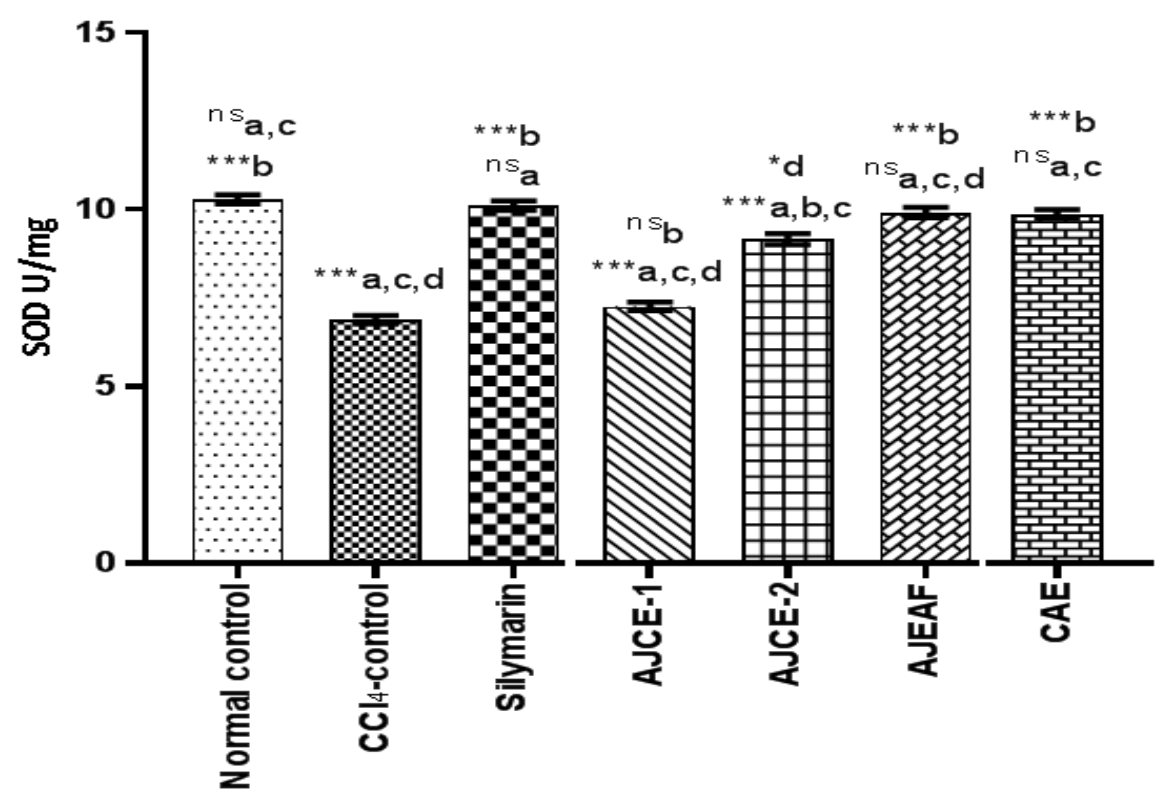

Results analyzed statistically using 1-way ANOVA followed by post hoc Tukey's multi-comparison test. Results compared with control (a), CCl4 control, standard silymarin (c) and CAE (d) herbal standard with all groups. Significance level represented as $*(\mathrm{p}<0.05), * *(\mathrm{p}<0.01), * * *(\mathrm{p}, 0.001)$, ns- no significant different.

Figure 4: In-vivo antioxidant activity- effect on Superoxide dismutase (SOD) activity

On comparing with control, an improvement in catalase level was seen with AJCE $\left(0.61\right.$ and $0.72 \mu \mathrm{M}$ of $\mathrm{H}_{2} \mathrm{O}_{2}$ decomposed / $\mathrm{min} / \mathrm{mg}$ wet tissue respectively with increasing doses) and AJEAF $\left(0.78 \mu \mathrm{M}\right.$ of $\mathrm{H}_{2} \mathrm{O}_{2}$ decomposed / min / mg wet tissue $)$ including standards. Low dose AJCE $(250 \mathrm{mg} / \mathrm{kg}$ b.w.) could not elevate the CAT to a significant level. Overall trend show an increase in CAT level with increase in dose. AJEAF showed better results than mother extract in any dose.

An impressive improvement in glutathione peroxidase (GSH) level was seen with mother extracts and fraction, though AJEAF was the best performing one with $4.56 \mu \mathrm{g} / \mathrm{mg}$ wet tissue GSH level when compared with $\mathrm{CCl}_{4}$ intoxicated control. Same order was followed in elevation of GSH level when compared with standards- silymarin and CAE. Dose dependant elevation in GSH level was seen with extract.

LPO level was determined by determining MDA level in tissues. An increase in LPO level is indication of increased oxidation. Therefore, decrease in LPO level in terms of MDA is an indication of reduced oxidative stress. In the present study, there was a significant increase in MDA level in $\mathrm{CCl}_{4}$ intoxicated control group. AJCE mother extract and its fraction AJEAF showed dose dependant decline in MDA level with best performing fraction AJEAF with 51.65 $\mathrm{nM} / \mathrm{mg}$ MDA level. Similar results were obtained when compared with standards- silymarin (40.64 nM/mg) and CAE (46.81 nM/mg).

Similar results were obtained with AJ complete hydroalcoholic extract (7.26 and $9.16 \mathrm{U} / \mathrm{mg}$ wet tissue with increasing doses) and fraction- AJEAF (9.91U/mg wet tissue) with significant improvement in SOD levels when compared with $\mathrm{CCl}_{4}$ intoxicated control. A dose dependant improvement was seen within extracts. Results show same trend when compared with standards- silymarin and CAE.

In general, all extracts were found beneficial in improving CAT, GSH, LPO and SOD levels. Ethyl acetate fraction shown superior activity. Potential of extracts to reduce or inhibit generation of free radical is important, as $\mathrm{CCl}_{4}$ induces liver lesion by elevating levels of free radical. Therefore a suitable radical scavenger can provide protecting against detrimental effect of $\mathrm{CCl}_{4}$ by not only scavenging radicals but also by elevating levels of endogenous antioxidant mechanisms. ${ }^{20-21}$

An increase in level of lipid peroxidation is a measure of structural functions due to membrane damage or alterations. MDA, being one of the end products of lipid peroxidation in liver tissue, is used as marker as its level was found high in $\mathrm{CCl}_{4}$ control group. Increased MDA level implies to failure of antioxidant defense mechanisms against free radicals leading to tissue damage. ${ }^{22-23}$ Treatment with extracts and Silymarin significantly reversed these changes.

Our body has an effective defense system against free radical induced damage. It consists of a set of endogenous antioxidant enzymes, two of the key components of which is catalase (CAT) Superoxide dismutase (SOD). Regarding non-enzymic antioxidants, reduced glutathione (GSH) is a critical determinant of tissue susceptibility to oxidative damage. $^{24-25}$ It is an intracellular reductant which is extensively found in cells. It protects cells against electrophilic attacks by xenobiotics such as free radicals peroxides. In the present study it is observed that $\mathrm{CCl}_{4}$ depletes GSH concentration in the rat livers. Extracts and Silymarin treatment reverses this effect, which may be due to de novo GSH synthesis or GSH regeneration. 
Better activity of ethyl acetate fraction of hydro-alcoholic extract might be attributed to the presence of high levels of polyphenolic components, as depicted by the phytochemical investigation done in pharmacognostic evaluation section of the present study. ${ }^{26}$

\section{CONCLUSION}

From the results of present study, this can be concluded that extracts in study possess powerful antioxidants which are more firmly distributed in diethyl ether and ethyl acetate fractions. The possibility of counteracting oxidative stress by a pool of proper antioxidants plus an appropriate diet, mainly in patients whose blood antioxidant deficiencies can be easily

\section{REFERENCES}

1. Nair S, Nair M, Nair D, Juliet S, Padinchareveetil S, Samraj S, et al. Wound Healing, Anti Inflammatory Activity and Toxicological Studies of Leea Asiatica (L.) Ridsdale. Int J Biol Pharm Res. 2014;5(9):745-9.

2. Kirtikar K, Basu B. Indian Medicinal plants Plates. 1918; 4:791

3. Chopra R, Nayar S, Chopra I. Glossary of Indian Medicinal Plants. CSIR,(New Delhi, India). 1956; 186-7.

4. Zaveri M, Movaliya V, Setty MM. Pharmacognostical Studies on Aerial Parts of Aerva javanica. Adv Res Pharm Biol. 2012; 2(III):250-3.

5. Soliman MA. Cytogenetical studies on Aerva javanica ( Amaranthaceae ). Flora Mediterr. 2006; (16):333-9.

6. Khunteta A, Swarnkar S, Gupta M, Swarnkar A, Jain P, Paliwal S Assessment of In-Vitro Antioxidant Potential of Ethyl Acetate Fraction of Hydroalcoholic Extract of Aerva Javanica Linn. Flowering Tops. Asian J Pharm Res Dev, 2019; 7(5):133-6.

7. Swarnkar S, Parnami A, Barotia K, Kumar Gupta M, Sharma D, Paliwal S. Phytochemical standardization of extracts of Aerva javanica Linn. flowering tops through determination of total phenolic, flavonoid and flavonol content. Asian J Biochem Pharm Res, 2019;(SI):12-6.

8. Swarnkar SK, Dwivedi D, Sharma R, Gupta D, Kaushik K, Gupta P. Assessment of superoxide scavenging and total antioxidant potential of hydroalcoholic extract of Aerva javanica Linn. flowering tops. Asian J Biochem Pharm Res 2019;(SI):22-6.

9. Manda H, Rao BK, Yashwant, Kutty NG, Swarnkar A, Swarnkar SK. Antioxidant, Anti-Inflammatory and Antipyretic Activities of Ethyl Acetate Fraction of Ethanolic Extract of Schrebera swietenioides roxb. Root. Int J Toxicol Pharmacol Res. 2009; 1(1):7-11.

10. Swarnkar S, Jain Y, Kumawat M, Khunteta A, Paliwal S. Exploration of autonomic involvement in mechanism of antinociceptive activity of flowering top extract of Aerva javanica. Asian J Biochem Pharm Res. 2019; (SI):33-6

11. OECD/OCDE. OECD guideline for testing of chemicals: Acute oral toxicity. 2001; 12

12. Laxane SN, Swarnkar SK, Zanwar SB, Manjunath Setty M. Antiinflammatory studies of the alcoholic extract of Zornia gibbosa. Pharmacologyonline. 2011; 1:67-76.

13. Naskar S, Islam A, Mazumder UK, Saha P, Haldar PK, Gupta M. In Vitro and In Vivo Antioxidant Potential of Hydromethanolic Extract of Phoenix rebalanced, may have real health benefit and represent a promising way of inhibiting the progression of disease.

\section{ACKNOWLEDGEMENT}

Authors acknowledge Dr. Rakesh Gupta, Principal, LBS College of Pharmacy, Jaipur and administration of Banasthali Vidyapith, Rajasthan for allowing and supporting for the work and also Dr. Ankit Arora, Indian Herbs for providing standards for work.

\section{Declaration of Interest Statement}

The authors report no declarations of interest.

dactylifera Fruits. J Sci Res. $2010 ; 2(1): 144-57$.

14. Ohkawa H, Ohishi N, Yagi K. Assay for lipid peroxides in animal tissues by thiobarbituric acid reaction. Anal Biochem. 1979; 95(2):351-8.

15. Onoja SO, Omeh YN, Ezeja MI, Chukwu MN. Evaluation of the in vitro and in vivo antioxidant potentials of Jatropha tanjorensis methanolic leaf extract. J Trop Med. 2014;6.

16. Draper HH, Hadley M. Malondialdehyde determination as index of lipid peroxidation. Methods Enzymol. $1990 ; 186: 421-31$.

17. Marklund S, Marklund G. Involvement of the Superoxide Anion Radical in the Autoxidation of Pyrogallol and a Convenient Assay for Superoxide Dismutase. Eur J Biochem. 1974; 47:469-74.

18. Sumner J, Somers G. Chem. and methods of enzymes. 2nd ed. New York; 1947. 209 p.

19. Ellman GL. Tissue sulfhydryl groups. Arch Biochem Biophys. 1959; 82(1):70-7.

20. Mohamed Saleem TS, Madhusudhana Chetty S, Ramkanth S, Rajan VST, Mahesh Kumar K, Gauthaman K. Hepatoprotective herbs - A review. Int J Res Pharm Sci. 2010; 1(1):1-5.

21. Nagano K, Umeda Y, Senoh H, Gotoh K, Arito H, Yamamoto S, et al. Carcinogenicity and chronic toxicity in rats and mice exposed by inhalation to 1,2-dichloroethane for two years. J Occup Health. 2006; 48(6):424-36.

22. Zama D, Meraihi Z, Tebibel S, Benayssa W, Benayache F, Benayache S, et al. Chlorpyrifos-induced oxidative stress and tissue damage in the liver, kidney, brain and fetus in pregnant rats: The protective role of the butanolic extract of Paronychia argentea L. Indian J Pharmacol. 2007; 39(3): 145 .

23. Abdel-Sattar EA, Mouneir SM, Asaad GF, Abdallah HM. Protective effect of Calligonum comosum on haloperidol-induced oxidative stress in rat. Toxicol Ind Health. 2014;30(2):147-53.

24. Malomo SO, Ore A, Yakubu MT. In vitro and in vivo antioxidant activities of the aqueous extract of Celosia argentea leaves. Indian J Pharmacol. 2011; 43(3):278-85.

25. Alici E, Arabaci G. Determination of SOD, POD, PPO and CAT Enzyme Activities in Rumex obtusifolius L. Annu Res Rev Biol, 2016; 11(3):1-7.

26. Mabeau S, Baty-Julien C, Hélias AB, Chodosas O, Surbled M, Metra P, et al. Antioxidant activity of artichoke extracts and by-products. Acta Hortic. 2007; 730:491-6. 